\title{
The role of psychiatry in genetic prediction programmes for Huntington's disease
}

\author{
G. E. Berrios, I. S. Marková and R. Gimbrett
}

\begin{abstract}
Poychiotitsts are becoming increasingly involved in the asessement of candidates for gonetic testing for Huntington's disecese (HD) in which theit role ranges from diagnoding conventional poychiotile disorder to Identitying 'now odd behoviours'. They cre olso expected to prectict dyefunctionet response to thet results (0.g. sellhorm). This peper describes the poychiotile component of the Cambildos HD Cinic and its asesesment proflocols. Proctical concepts, usefut to the understanding of the clinical problems that may be encountered, cre clso discuseed.
\end{abstract}

Psychiatric disorder is a central clinical component of Huntington's disease (HD) and psychiatrists are involved in its management (Roccatagliata, 1979; Folstein, 1989; Harper, 1991; Watt \& Seller, 1993). More recently, new opportunities have become available for psychiatric intervention. Programmes for presymptomatic testing for HD (Tyler et al, 1992) have since 1983 required help with prediction and management of dysfunctional reactions to test results (e.g. suicidal behaviour), diagnosis and management of conventional psychiatric disorder, and research. More recently, psychiatrists are also being offered the opportunity of becoming members of newlyformed 'brain repair teams' where they will be expected to help with the assessment, selection, and preparation of patients for cell transplantation, and also act as stress specialists. It seems clear that such demands may challenge traditional psychiatric skills, concepts, and measuring instruments. This short paper deals only with psychiatric intervention in pre-symptomatic testing which can be clinical or research-related (Fig. 1).

\section{Clinical interventions}

Clinical involvement concerns the prediction of post-test negattve reaction and the diagnosis and management of psychiatric disorder in $50 \%$ risk candidates. The former concerns the search for predictors (in mental state, personality, past history, etc.) of dysfunctional outcome to posittve or negative test results (Martindale, 1987). In most cases, such indicators must be detected in subjects who can be described as 'normal' from the psychiatric point of view. There is not yet much evidence that traditional indicators such as impulsivity, intro-punitiveness, tendency to depression, and previous suicidal attempts are of particular use in this field.

Table 1. Cambridge HD Clinic: computerised psychiatric assessment

\begin{tabular}{|c|c|}
\hline $\begin{array}{l}\text { General } \\
\text { General Health Questionnaire: } \\
\text { DSM-III-R diagnosis (MINISCID) } \\
\text { Insight Scale } \\
\text { Personality Deviance Scale }\end{array}$ & $\begin{array}{l}\text { Code } \\
\text { GHQ } \\
\text { SCID } \\
\text { INS } \\
\text { PER }\end{array}$ \\
\hline $\begin{array}{l}\text { ANective divorders } \\
\text { Hamilton Depression Scale (observer rated) } \\
\text { Profile of Mood States } \\
\text { Inttabilly Scale } \\
\text { Hospltal Anxiety Depression Scale } \\
\text { Mania Scale } \\
\text { Beck Depression Inventory }\end{array}$ & $\begin{array}{l}\text { HDS } \\
\text { POMS } \\
\text { IRR* } \\
\text { HAD } \\
\text { MAN } \\
\text { BECK" }\end{array}$ \\
\hline $\begin{array}{l}\text { Cognilive } \\
\text { Attention Test } \\
\text { Signal Detection Memory Test } \\
\text { Metamemory Test } \\
\text { Cognitive Failures Questionnalre }\end{array}$ & $\begin{array}{l}\text { AIT" } \\
\text { SIGNAL" } \\
\text { MET } \\
\text { CFQ }\end{array}$ \\
\hline $\begin{array}{l}\text { 'Neurolic' behoviour } \\
\text { Obsesstons interference/resistance } \\
\text { Obsesstve-compulstive disorder } \\
\text { Hypochondila Scale } \\
\text { Zung Andety Scale } \\
\text { Phobias Scale } \\
\text { Dissoclative Behoviours Questionnaire }\end{array}$ & $\begin{array}{l}\text { OCD } \\
\text { MOC. } \\
\text { HYP } \\
\text { ZG } \\
\text { PHO } \\
\text { DIS" }\end{array}$ \\
\hline
\end{tabular}

"Core battery 


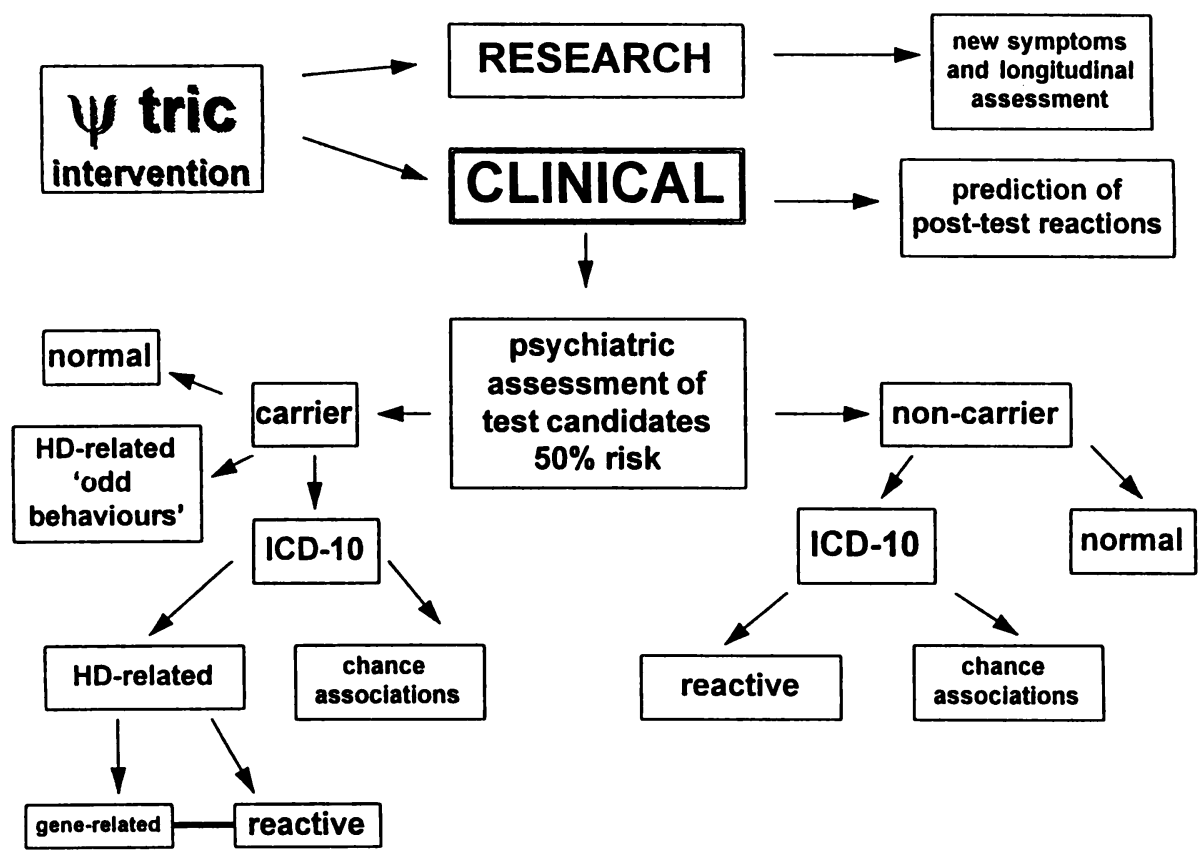

Fig. 1. Psychiatric intervention in pre-symptomatic testing which can be clinical or research-related

After genetic testing, candidates fall into a carrier or a non-carrier category. From the psychiatric viewpoint, the former may be asymptomatic, have conventional (ICD-10) psychiatric disease, or show 'odd behaviours' which do not fit into any ICD-10 category (This group will be discussed later). Conventional psychiatric disease in carriers may be theoretically divided according to whether it is related to $\mathrm{HD}$ or 'coincidental' (e.g. major depression may be a chance association of HD). In practice, this separation is difficult to make but the distinction remains important from the clinical and research viewpoints. The group in whom psychiatry and HD are related can in turn be (theoretically) divided according to whether the psychiatric disorder is dependent upon the specific changes of HD or is 'reactive' (e.g. brought about by a pathological HD environment). Non-carriers can be also psychiatrically normal or abnormal, and the latter sub-divided into those whose disorder is 'reacttve' to being brought up in a HD environment and those whose mental disorder is but a chance association.

\section{Assessments}

The assessment of pre-symptomatic subjects is carried out in the conventional way and should lead when applicable to an ICD-10 diagnosis. In the Cambridge HD clinic the procedure lasts about 90 minutes, roughly divided into $\mathbf{4 0}$ minutes for the interview, 40 for computerised testing, and about 10 to interview relatives. Computerised testing is carried out on personal computers distributed at various testing points (including an outpost in Norwich). The tests are computerised in Q-language and the battery of 20 questionnaires and tests includes the SCID which leads to a DSM-III$R$ diagnosis (Table 1; core tests are starred). The same set is used for the evaluation of all neuropsychiatric and general patients, and also in the Cambridge Memory Disorders Clinic and Sleep Disorders Clinic so that a considerable amount of data has accumulated. On the same day, candidates attending the Cambridge HD Clinic also undergo full neuropsychological and 
neurological assessment, and assessors are blind to each other's findings. Efforts are being made at the moment to develop a common assessment protocol to all predictive programmes in the UK and in the European community.

It is hoped that the psychiatrist would also play a role in the analysis and resolution of the ethical issues that may arise in genetic testing. The general principles governing this field have been well studied (Mastromauro et al. 1987; Smurl \& Weaver, 1987; Kessler et al., 1987; Meissen \& Berchek, 1987; Shaw, 1987; EverKiebooms et al, 1987) but new problems always emerge. As the member of the HD with expertise in the analysis of human relationships, the psychiatrist's contribution should be particularly illuminating. At a more practical level, good ethical management also includes the treatment of dysfunctional reactions in testees and the analysis of tensions affecting the psychodynamics of the HD team itself.

\section{Research}

Research in the field of presymptomatic testing raises the question of whether the conventional assessment techniques and instruments are adequate (i.e. sensitive and valid) enough. The answer to this will depend on the objectives of the research (i.e. the type of 'caseness' it requires). For example, if it is to establish the prevalence of conventional psychiatric disorder then the usual approach may suffice; even then the fact that reports of rates of psychiatric morbidity in HD range from 25 to $80 \%$ (Harper, 1991) seems to suggest that the conventional approach is not working well. If, however, the objective of the research is to find new behavioural (or other) markers of gene-carrying status (in apparently asymptomatic subjects) then the conventional assessments will be singularly unhelpful.

For example, it has been suggested that gene carriers show since childhood subtle oddities of behaviour. A mother may say that an HD patient was behaviourally 'different' and that she 'knew' that he/she was going to develop the disease. Such claims can, of course, be rejected as retrospective falsification, but it is also possible that they do reflect some real change. Whatever this change might be, it will need to be described anew as it is likely to differ from any conventional 'symptom'.
The fact that such odd behaviours have not yet been fully described can be explained in a number of ways.

(a) They may be faint conventional symptoms and hence not within the resolution power (sensitivity) of conventional instruments.

(b) They may be forms of experience or behaviour which are different in quality to conventional symptoms and hence are difficult to describe: for example, it is not uncommon for subjects suffering from neurological disorder to report strange experiences for which the psychiatrist has no name; these reports may be ignored altogether or forced into a known category (Berrios \& Samuel, 1987).

(c) Such changes in behaviour may be difficult to capture on account of the rate at which they develop: the slower the installation of a new behaviour or experience the higher the chance that it will be missed out altogether.

(d) It could be that what is abnormal is the temporal organisation of behaviour (this is a hypothesis in which we are particularly interested): for instance, an impression of odd behaviour may not be caused by oddity attached to any single behavioural episode but by dislocations of the longitudinal coherence or integration of 'normal' behavioural episodes. Since the mental state examination is not principally geared to capturing longitudinal behaviour, such information can be missed out altogether. The child's mother, however, has privileged access to longterm observation and can notice subtle dislocations even if she lacks the appropriate language of description.

(e) Oddities of behaviour may only become manifest in certain social contexts (e.g. home) or triggered by other behaviours.

\section{Summary and conclusions}

Subjects with a $50 \%$ risk of developing HD may or may not show conventional psychiatric disorder. Those with higher risk may also exhibit abnormal behaviours (expression of the HD gene) which do not amount to conventional psychiatric illness and resist easy description. The description and 
measurement of such 'symptoms' requires imaginative mapping of behaviour both in the cross-section and longitudinally. The first step, however, should be to record conventional symptoms (not diseases) on multi-dimensional scales (e.g. irritability. fatigue, intro- and extra-punittveness, depersonalisation-like experiences, increases in vague somatic complaints, impulsivity, dissociation between spontaneous and reactive behaviours, etc.) so that more sensitivity and fine-grain can be achieved. General instruments such as the AMDP (Guy \& Ban, 1982) are based on an 'open' view of psychopathology and are particularly useful in this regard. Individual scales for symptoms (as opposed to diseases) are also beginning to appear. In addition, an attentive listening to the descriptions and experiences of testees should help to identify some of these new 'symptoms'. The longitudinal mapping of behaviour is even harder but may prove to be the only way of eventually finding specific psychopathological markers for HD.

\section{References}

Berroos, G. E. \& SAMUre, C. (1987) Affective disorder in the neurological patient. Joumal of Nervous and Mental Disease, 178. 173-176.

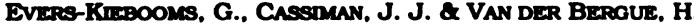
(1987) Attitudes towards predictive testing in Huntington's disease: a recent survey in Belgium. Joumal of Medical Cenetics, 24, 275-279.

FOLSTEN, S. E. (1989) Hunttington's Dlsease. Baltmore: The Johns Hopldns Untversity Press.

GUY, W. \& BNN, T. A. (1982) The AMDP system. Manual for the Assessment and Documentation of Psychopathology. Berilin: Springer.
HARPER, P. S. (ed) (1991) Hunttington's Disease. London: Saunders.

KESSLER, S., FELD, T., WORTH, L. \& MOSBARGER, H. (1987) Attitudes of persons at risk for Huntington disease towards predictive testing. American Joumal of Medical Genetics, 28. 259-270.

MARTINDALE, B. (1987) Huntington's chorea. Some poychodynamics seen in those at risk and in the responses of the helping professions. Brttish Joumal of Psychiatry. 160. 319-323.

MAstromauro, C., MYeres, R. H., \& BERroman, B. (1987) Attitudes toward presymptomatic testing in Huntington Discase. American Joumal of Medical Genetics, 28. 271282.

Menssen, G. J. \& Bercherk, R. L. (1987) Intended use of predictive testing by those at risk for Huntington Disease. American Journal of Medical Genetics, 28, 283-293.

Roccatacunta, G. (1979) Pstcost e Corea di Hunttington Pisa, Pacini Editore.

SHAw. M. W. (1987) Testing for the Huntington gene. American Joumal of Medical Cenetics, 28, 243-246.

SMURe, J. F. \& WEAVER, D.D. (1987) Presymptomatic testing for Huntington chorea. American Journal of Medical Genetics, 28, 247-257.

TYLRR, A., Ball, D. \& CraUruro, D. (1992) Presymptomatic testing for Huntington's disease in the United Kingdom. Brtish Medical Joumal, so4, 1593-1596.

WATT, D. C. \& SEuzR, A. (1993) A clinico-genetic study of poychlatric disorder in Huntington's chorea. Psychological Medictne Monograph Supplement 23. Cambridge: Cambridge Untveraity Press.

G. E. BERRIOS, Consultant and Universthy Lecturer in Neuropsychiatry; I. S. MARKOVh. Senior Registrar in Psychiatry; and R. GMBRETT, Senior Registrar in Psychiatry, Department of Psychiatry, University of Cambridge, Addenbrooke's Hospital (Box 189), Hills Road, Cambridge 